\title{
Development of Tax Stimulation and Business Environment in Slovakia
}

\author{
Ivona Ďurinová ${ }^{1, *}$, Natália Tačarová ${ }^{2}$ \\ ${ }^{1}$ University of Economics, Faculty of Business Management, Department of Corporate \\ Finance, Dolnozemská cesta 1,852 35 Bratislava, Slovakia \\ ${ }^{2}$ Slovenská sporitel’ňa, a. s., Tomášikova 48, 83237 Bratislava, Slovakia
}

\begin{abstract}
Tax incentives are specific and targeted tax instruments in the economic and social policy of the state. With appropriate tools, the state can support the creation of new jobs and also the sustainability of human resources in existing companies. The article deals with the issue of stimulation of companies in Slovakia and the suitability of the applied incentives in connection with the business environment. The aim of the paper is to approach and analyze the impact of tax incentives applied in the Slovak Republic and evaluate them based on their impact on business entities, respectively business environment. The analysis of the overall development of provided tax incentives in the Slovak Republic is focused on the period from 2002 to 2018 . The paper uses the method of analysis and synthesis together with the methods of tabular and graphical representation. Mathematical and statistical methods are used in individual calculations. On the one hand, it can be stated that tax incentives are important, even necessary, for countries, given the inflow of foreign capital, but on the other hand, domestic businesses are disadvantaged by which foreign investors disrupt the domestic business environment.
\end{abstract}

\section{Introduction}

The business environment also includes the country's tax system, which should be simple and transparent in order to create favorable conditions for doing business. It should be borne in mind that not only differences in individual countries but also any change in the field of income taxation in a given country affects the behavior of business entities. Many authors are researching this fact. Harumová [1] examines how the tax system affects work as well as business activity, the amount of savings and investor decision-making. Investors' decisions are often influenced by various constructed tax incentives. Tax incentives are specific and targeted tax instruments in the economic and social policy of the state, through which the state influences the behavior of economic entities in order to achieve its goals. With the help of taxes, the state can support investment and business, regional development, innovation and scientific and technical development, dampen production in certain sectors, etc. [2]. With appropriate tools, the state can support the creation of new

\footnotetext{
*Corresponding author: ivona.durinova $@$ euba.sk
} 
jobs and also the sustainability of human resources in existing companies. Incentives are often provided to large companies, but many authors point out that small and medium-sized enterprises (SMEs) are considered globally to be the driving force behind economic growth, enabling job creation and increased productivity [3]. Other authors [4] point to the fact that SMEs are facing internal markets with higher taxation and transfer price compliance costs as well as cross-border loss compensation problems. In particular, the works of Michael Porter [5], Matatková and Stejskal [6] focus on companies in terms of their possibilities for regional and local grouping. In the case of small and medium-sized enterprises, networking is usually one of the many ways to become competitive compared to strong and often highly sophisticated partners. Gajdová [7] sees the cluster as a joint union of independent, regionally unified, jointly supporting companies and institutions that have the potential to be competitive within EU regions. In this way, the merged companies can achieve a synergistic effect.

The article deals with the issue of stimulation of companies in Slovakia and the suitability of the applied incentives in connection with the business environment. The aim of the paper is to approach and analyze the impact of tax incentives applied in the Slovak Republic and evaluate them based on their impact on business entities, respectively the business environment. The partial goals are as follows: to perform an analysis of the applied tax incentives, to evaluate the state of the business environment in the Slovak Republic, to evaluate the impact of tax incentives in relation to the basic principles of taxation.

\section{Methods}

The paper uses the method of analysis and synthesis together with the methods of tabular and graphical representation. Mathematical and statistical methods are used in individual calculations. In the final phase, attention is focused on summarizing the data obtained. In this part, the method of synthesis (summary of the obtained results) and the method of comparison are used, through which the effectiveness of the applied incentives in the Slovak Republic is compared and analyzed.

\section{Results}

The analysis of the overall development of provided tax incentives in the Slovak Republic is focused on the period from 2002 to 2018. The total number of issued decisions for the monitored period was 211 and reached the amount of almost 2 billion $€$. However, the number of beneficiaries is lower, due to the fact that some companies have benefited more than once. Companies that have benefited twice are: Continental Automotive Systems Slovakia s.r.o., Dell s.r.o., Embraco Slovakia s.r.o., Holcim Business Services s.r.o., OSRAM, a.s., Mondi SCP, a.s., SAMSUNG Slovakia s.r.o., PCA Slovakia, s.r.o., Magneti Marelli, s.r.o. and Johnson Controls, s.r.o. Companies that have benefited from tax incentives even three times are: Kia Motors Slovakia s.r.o., T-Systems Slovakia s.r.o., ZKW Slovakia s.r.o. and SCA Hygiene Products Slovakia, s.r.o. The highest number of incentives was recorded in 2006 and this year the volume of these incentives was also the highest. In 2005, no incentives were provided by the state [8].

Figure 1 shows the development of the provided incentives for the total monitored period. In the last three years, there has been a growing trend in the incentives provided, to which the legislative changes adopted at the end of 2015 have also contributed. Legislative changes have simplified access to incentives for businesses in the least developed regions. 
The largest volume of incentives provided was in 2004, 2006 and 2015. For these years, the number of planned jobs created was also the highest.

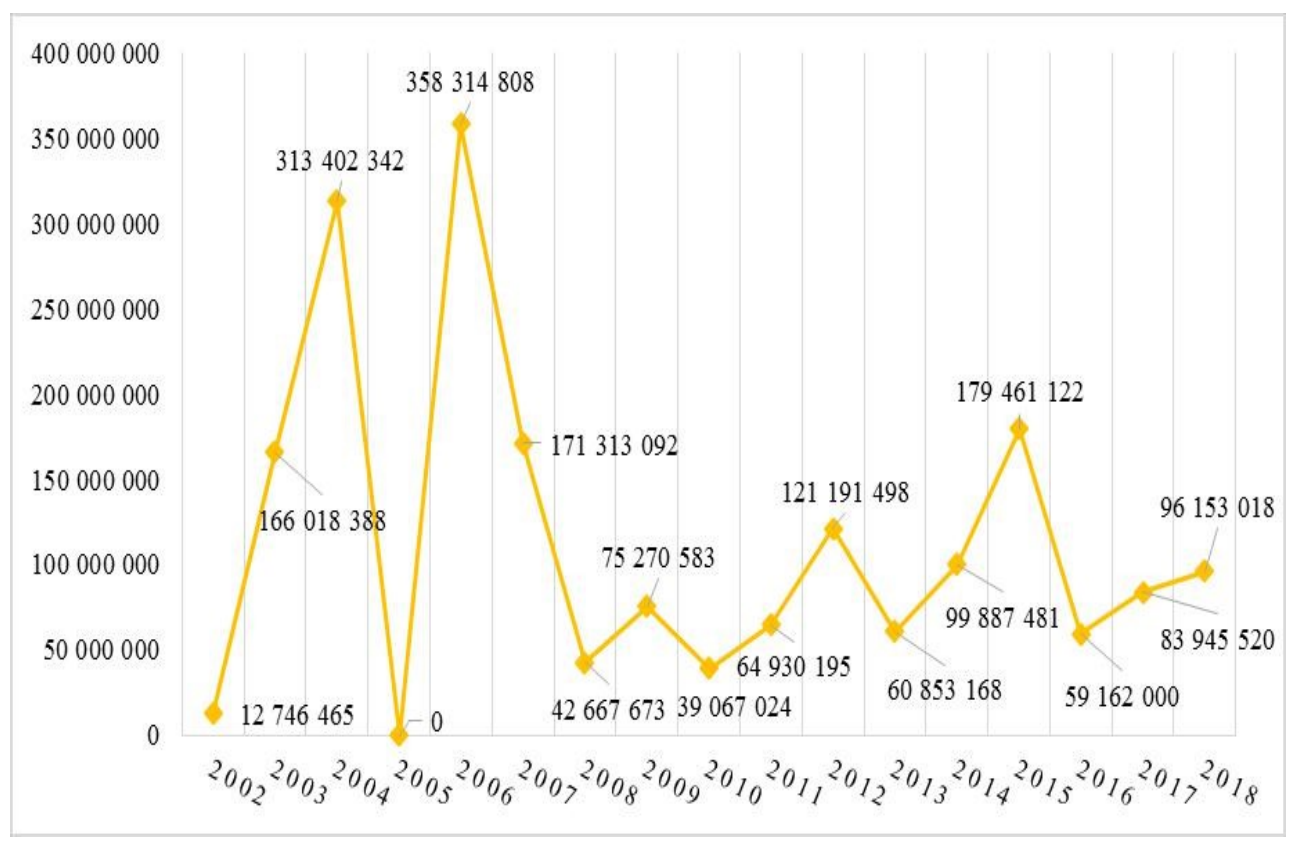

Fig. 1. Development of provided incentives for the period from 2002-2018 in € [8]

It was planned to create 64,539 jobs for the entire period under review. The average cost of such one job was $€ 28,463$. We can note that most jobs were to be created in 2006, which was also due to the highest number of approved incentives for the whole period. On the contrary, the least jobs were to be created in 2002, when only one incentive was provided. In processing these results, it was necessary to take into account the fact that in 2014 , out of the total volume of incentives in the amount of $€ 99,887,481$, a tax incentive was provided to Duslo, a. s. amounting to $€ 58,560,000$, with the company not planning to create any new jobs and the incentive being approved only in the form of a tax credit. The same situation occurred in 2018, when out of the total volume of provided incentives in the amount of $€ 96,153,018$, a tax incentive was provided to Mondi SCP, a. s. This company was also not created by creating new jobs and the incentive was provided only as a tax relief. Figure 2 shows the cost per job in each year. The lowest cost per job was in 2018. We recorded a more significant decline in 2008 , which can be attributed to the economic crisis. From 2009 to 2012, we see a growing trend in these costs. 


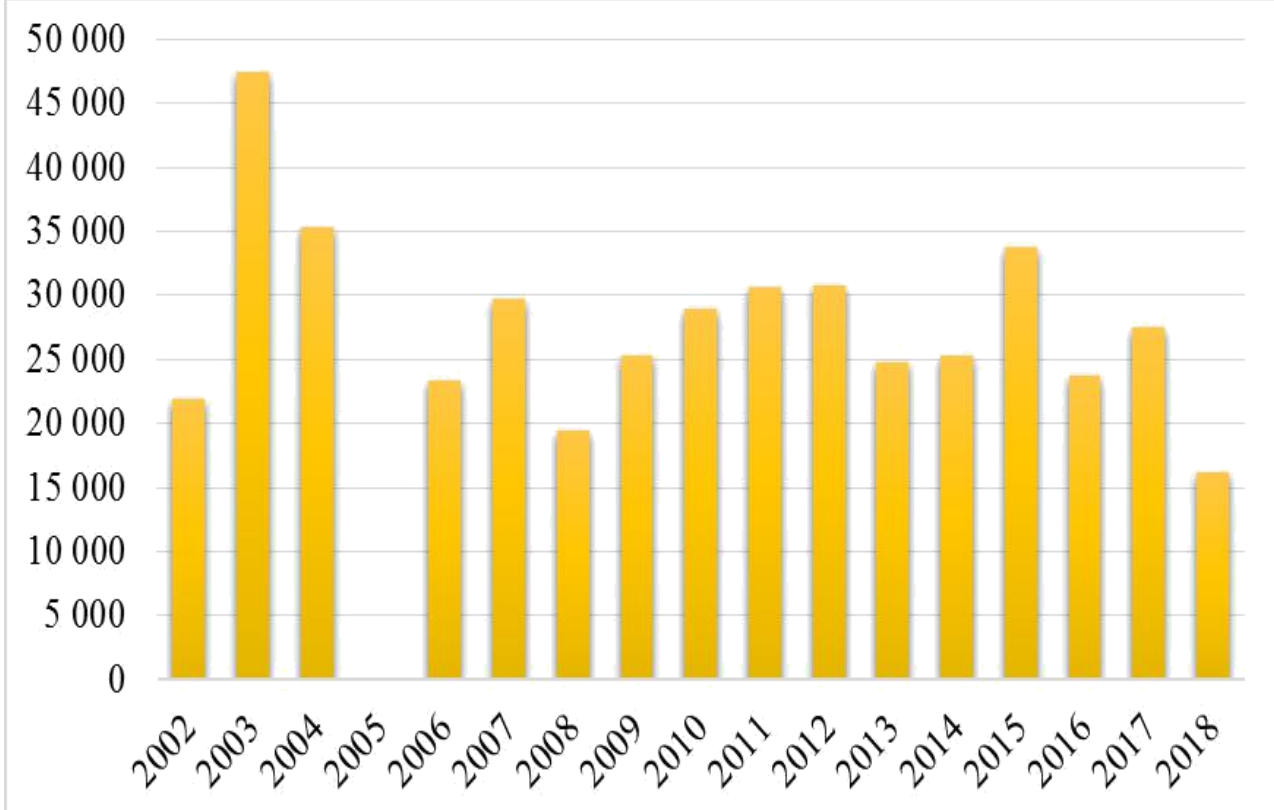

Fig. 2. Overview of costs per job in individual years [8]

Table 1 provides an overview of all beneficiaries by country of origin, together with the percentage on total incentives provided.

Table 1. Beneficiers of incentives by country of origin [8]

\begin{tabular}{|l|r|r|l|r|r|}
\hline $\begin{array}{l}\text { Country of } \\
\text { origin }\end{array}$ & $\begin{array}{r}\text { Sum of } \\
\text { incentives in } €\end{array}$ & \% share & $\begin{array}{l}\text { Country of } \\
\text { origin }\end{array}$ & $\begin{array}{r}\text { Sum of } \\
\text { incentives in } €\end{array}$ & \% share \\
\hline Belgium & 6797500 & 0,35 & Hungary & 10202574 & 0,52 \\
\hline Brazil & 1991635 & 0,10 & Malaysia & 38268000 & 1,97 \\
\hline $\begin{array}{l}\text { Czech } \\
\text { Republic }\end{array}$ & 62641126 & 3,22 & Norway & 1163372 & 0,06 \\
\hline China & 5550000 & 0,29 & Poland & 531600 & 0,03 \\
\hline Denmark & 9110333 & 0,47 & Austria & 85606121 & 4,40 \\
\hline France & 193277550 & 9,94 & Russia & 3160061 & 0,16 \\
\hline GB & 129812750 & 6,68 & Slovakia & 127839132 & 6,57 \\
\hline Netherlands & 176461902 & 9,08 & Germany & 232917375 & 11,98 \\
\hline Hong Kong & 38800372 & 2,00 & Spain & 37700047 & 1,94 \\
\hline Ireland & 652000 & 0,03 & Switzerland & 49408108 & 2,54 \\
\hline Iceland & 3264883 & 0,17 & Sweden & 7928607 & 0,41 \\
\hline Japan & 19250000 & 0,99 & Italy & 70312898 & 3,62 \\
\hline $\begin{array}{l}\text { Cayman } \\
\text { Islands }\end{array}$ & 11405306 & 0,59 & Ukraine & 18000000 & 0,93 \\
\hline $\begin{array}{l}\text { Republic of } \\
\text { Korea }\end{array}$ & 450114343 & 23,15 & USA & 109814425 & 5,65 \\
\hline Luxemburg & 42402357 & 2,18 & Total & $\mathbf{1 9 4 4 3 8 4 3 7 7}$ & $\mathbf{1 0 0 , 0 0}$ \\
\hline
\end{tabular}

The largest beneficier of the incentives provided is the Republic of Korea with a share of $23.15 \%$ for the entire period under review. Another country is Germany with an $11.98 \%$ share, followed by France, which has a 9.94\% share. These three countries were thus 
granted incentives in the amount of $€ 876,309,268$, which represents $45.07 \%$ of all incentives provided. Incentives in the amount of $€ 127,839,132$ were allocated to Slovak business entities for the total monitored period, which represents $6.57 \%$. Slovakia placed 6th. In addition to the already mentioned Republic of Korea, Germany and France, the Netherlands and the United Kingdom are in the top five. Businesses from Russia, Brazil, Norway, Ireland and Poland received the smallest volume of incentives provided.

The total amount of incentives consists of several parts. Table 2 shows the sums of these individual parts for the whole monitored period together with their percentage share.

Table 2. Breakdown of the total amount of incentives [8]

\begin{tabular}{|l|r|r|}
\hline \multicolumn{1}{|c|}{ Incentives } & \multicolumn{1}{|c|}{ Sum in $\boldsymbol{\epsilon}$} & \multicolumn{1}{c|}{$\%$ share } \\
\hline Subsidy for tangible and intangible fixed assets & 821613753 & 42,26 \\
\hline Contribution to created places & 126115264 & 6,49 \\
\hline Retraining allowance & 52512165 & 2,70 \\
\hline Tax relief & 897447568 & 46,16 \\
\hline Transfer of assets at a price below market value & 46695630 & 2,40 \\
\hline Total & 1944384380 & 100,00 \\
\hline
\end{tabular}

The most frequently provided incentive is the tax relief, which for the entire monitored period amounted to $€ 897,447,568$ and its percentage share was $46.16 \%$. The subsidy for tangible fixed assets and intangible fixed assets, which acquired the value of $€ 821,613,753$ for the entire monitored period, has a 3.90\% lower share.

Table 3 shows the impact of incentives that are applied in the Slovak Republic.

Table 3. Impact of tax incentives applied by the Slovak Republic

\begin{tabular}{|c|c|c|c|c|}
\hline Year & $\begin{array}{c}\text { The amount of } \\
\text { incentives } \\
\text { provided in mil. } €\end{array}$ & $\begin{array}{c}\text { The total volume of } \\
\text { collected corporate } \\
\text { income tax in mil. } €\end{array}$ & $\begin{array}{c}\text { Corporate tax } \\
\text { rate in \% }\end{array}$ & $\begin{array}{c}\text { New corporate } \\
\text { tax rate in\% }\end{array}$ \\
\hline $\mathbf{2 0 0 2}$ & 12,75 & 926,00 & 25,00 & $\mathbf{2 4 , 6 6}$ \\
\hline $\mathbf{2 0 0 3}$ & 166,02 & 1118,00 & 25,00 & $\mathbf{2 1 , 2 9}$ \\
\hline $\mathbf{2 0 0 4}$ & 313,40 & 1171,00 & 19,00 & $\mathbf{1 3 , 9 1}$ \\
\hline $\mathbf{2 0 0 5}$ & 0,00 & 1344,00 & 19,00 & $\mathbf{1 9 , 0 0}$ \\
\hline $\mathbf{2 0 0 6}$ & 358,31 & 1599,00 & 19,00 & $\mathbf{1 4 , 7 4}$ \\
\hline $\mathbf{2 0 0 7}$ & 171,31 & 1848,00 & 19,00 & $\mathbf{1 7 , 2 4}$ \\
\hline $\mathbf{2 0 0 8}$ & 42,67 & 2087,00 & 19,00 & $\mathbf{1 8 , 6 1}$ \\
\hline $\mathbf{2 0 0 9}$ & 75,27 & 1582,00 & 19,00 & $\mathbf{1 8 , 1 0}$ \\
\hline $\mathbf{2 0 1 0}$ & 39,07 & 1659,00 & 19,00 & $\mathbf{1 8 , 5 5}$ \\
\hline $\mathbf{2 0 1 1}$ & 64,93 & 1666,00 & 19,00 & $\mathbf{1 8 , 2 6}$ \\
\hline $\mathbf{2 0 1 2}$ & 121,19 & 1631,00 & 19,00 & $\mathbf{1 7 , 5 9}$ \\
\hline $\mathbf{2 0 1 3}$ & 60,85 & 1975,00 & 23,00 & $\mathbf{2 2 , 2 9}$ \\
\hline $\mathbf{2 0 1 4}$ & 99,89 & 2315,00 & 22,00 & $\mathbf{2 1 , 0 5}$ \\
\hline $\mathbf{2 0 1 5}$ & 179,46 & 2860,00 & 22,00 & $\mathbf{2 0 , 6 2}$ \\
\hline $\mathbf{2 0 1 6}$ & 59,16 & 2812,00 & 22,00 & $\mathbf{2 1 , 5 4}$ \\
\hline $\mathbf{2 0 1 7}$ & 83,95 & 2995,00 & 21,00 & $\mathbf{2 0 , 4 1}$ \\
\hline $\mathbf{2 0 1 8}$ & 96,15 & 3167,00 & 21,00 & $\mathbf{2 0 , 3 6}$ \\
\hline
\end{tabular}

It is an overview of the amount of incentives provided in individual years, together with the total volume of corporate income tax collected and the relevant tax rate in individual years of the observed period. 
If we compare the amount of provided incentives with the total amount of collected corporate income tax in individual years, it is possible to determine what "new" corporate tax rate could have arisen. The most significant difference can be seen especially in 2004 . The difference between the tax rate applied at that time and the rate recalculated by us reached 5.09\%. Other significant differences relate mainly to 2003 and 2006, when in 2003 the rate could have been lower by $3.71 \%$ and in 2006 by $4.26 \%$. In recent years, such significant differences are no longer observable and the tax rate would fall by around $0.50 \%$, which was due to the lower volume of tax incentives provided.

It can be stated that if the approved incentives were not provided in individual years, it would have been possible to reduce the corporate tax rate in 2004 by even more than $5 \%$. Such a reduction would apply to all legal entities, and thus the advantage would benefit all entities, not just those to whom tax incentives have been approved.

Business entities have long been dissatisfied with the subsidy system in the Slovak Republic and consider it unfair. Peter Kremský from the Business Alliance of Slovakia also states that: "This should not be done through investment incentives for specific companies, but especially through improving the business environment in the region, such as improving infrastructure, developing local services, supporting education in the region, etc. The state would help investors the most by cutting red tape, corruption, simplifying tax rules and the labor market." [9]. A similar view is shared by Martin Vlachynský, who claims that he would welcome even more general measures, in the form of regional deductions, by adding in the construction of infrastructure, but also in the regionalization of the minimum wage [10].

\section{Discussion}

The development of the business sector is closely linked to the promotion of investments that would create more opportunities for economic growth and job creation [11].

According to Martin Vlachynský, we can state that: "In reality, there is a situation where some companies have consistently lower taxes compared to their competitors. In addition, there is a false impression that those who do not receive incentives from the government cannot do business in Slovakia, which does not benefit the business climate. "If companies receive such assistance repeatedly, the question may arise approve this support. However, the government should under no circumstances support companies that are unable to stay in the market. It is a waste of public resources and discrimination against entrepreneurs who "feed" other companies on taxes paid through incentives, with whom they are fighting for customers as well as potential workers [10].

On the one hand, it can be stated that tax incentives are important, even necessary, for countries, given the inflow of foreign capital, but on the other hand, domestic businesses are disadvantaged by which foreign investors disrupt the domestic business environment. The legal regulation of tax incentives is often incomprehensible and complicated for taxpayers, and therefore the state should start to pay more attention to their simplification. Markovič, Majdúchová and Rybárová [12] point to the fact that especially start-up small companies with high innovation potential encounter frequent and fundamental fluctuations of the business environment in which they try to plan and implement their activities. The state should focus mainly on improving the quality of the business environment, focusing on the elimination of bureaucracy, the stability of legislation and a level playing field for foreign and domestic entrepreneurs. In terms of economic efficiency, tax systems should ideally be "neutral", particularly as regards economic decisions. From this perspective, the location of investments in different countries in the international context should not face markedly different effect levels of taxation [13]. According to Clausing [14] and Mura [15] 
it is important to monitor the overall tax burden that represents the size of the enterprise's tax.

There are also options through which tax incentives could be replaced by solutions that could be used by all businesses and not just some. One of them would be, for example, to completely abolish tax incentives and instead reduce the tax burden across the board. Another alternative could be the auction of incentives, respectively. regional auction of incentives. Through this auction, the whole system would be more objective, clearer and companies that have not yet had such an opportunity would also be given incentives. The system would consist in the specified volume of funds being allocated to those applicants who would show e.g. the lowest possible cost per new job created. Another alternative could be to reduce the levies on low-income employees, which would compensate for the provision of investment incentives. Such a solution would affect a large part of the population and would also not significantly distort the competitive environment. The employer would have significantly lower costs per employee and at the same time the employee would have a higher net salary [16]. Dubcová [17] draws attention to the social and solidarity economy in Slovakia, where the stimulus system is lacking. She recommends the application of specific financial and economic instruments in this area (tax breaks, tax deductions, specialized system of the state supports, etc.).

\section{Conclusion}

Tax incentives are used by states in order to motivate businesses for a specific purpose, e.g. to support certain activities, to expand entrepreneurial activity to disadvantaged regions, to support research and development and others. However, the incentive function of taxes is contrary to the principle of neutrality. It can be stated that tax incentives distort the basic principles of market competition. If it is in the state's interest to attract foreign investors, it should focus primarily on improving the quality of the business environment and not just on offering incentives.

This paper is a partial output of the research project VEGA n. 1/0569/18: , STABILIZATION OF THE HUMAN CAPITAL IN SLOVAK ENTERPRISES AS AN IMMANENT DETERMINANT OF THEIR SUCCESS, COMPETITIVENESS AND SUSTAINABLE DEVELOPMENT" in the range of $100 \%$.

\section{References}

1. A. Harumová, Impact of Taxes on the Development of Business Sphere. Journal of Economics 50(2), 277-292 (2002)

2. G. Lénártová, Tax Stimulation and Business Environment in Slovakia. In Current Problems of the Corporate Sector 2014: Proceedings of International Scientific Conference. (Bratislava: Vydavatel'stvo EKONÓM, 2014)

3. D. Gajdová, G. Dubcová, M. Krechovská, New challenges of SMEs through clusters creation in Slovakia. In 3rd international conference on new challenges in management and business. International conference. $3 r$ international conference on new challenges in management and business : conference proceedings : Dubai, UAE, 2 may, 2016. [Tehran] : [Industrial Management Institute] (2016)

4. V. Solilová, D. Nerudová, M. Litzman, Application of the CCCTB and Safe Harbours to European SMEs: Can the Decrease in Compliance Costs Support better SME Performance? Journal of Economics 67(6), 587 - 606 (2019)

5. M. E. Porter, Location, Competition, and Economic Development: Local Clusters in a Global Economy. Economic Development Quarterly 14(1), 15-34 (2000) 
6. K. Matatkova, J. Stejskal, Assessment of Shift-share Analysis Suitable for Identification of Industrial Cluster Establishing in Regions. Journal of Economics $\mathbf{6 0}$ (3), 935-948 (2012)

7. D. Gajdová, Clusters and Cluster Initiatives in the Slovak Republic. In Current Problems of the Corporate Sector 2012: Proceedings of International Scientific Conference. (Bratislava: Vydavatel'stvo EKONÓM, 2012)

8. Ministry of Economy of the Slovak Republic, List of Entities to which Investment Aid has been approved. Avaliable at: <https://www.economy.gov.sk/podporainvesticii/investicna-pomoc/zoznamy/zoznam-podnikatelskych-subjektov-ktorymbolo-schvalene-poskytnutie-regionalnej-pomoci> (2019)

9. P. Kremský, Investment Incentives for Large Companies Distort the Business Environment and Harm Entrepreneurs. Avaliable at: https://www.alianciapas.sk/2016/03/24/investicne-stimuly-pre-velke-podnikydeformuju-podnikatelske-prostredie-a-poskodzuju-podnikatelov/ (2016)

10. D. Krajanová, The Government Repeatedly Subsidizes the Same Companies, and then it looks like others have no Place here. Avaliable at: $<$ https://iness.sk/sk/vladaopakovane-dotuje-tie-iste-firmy-potom-vyzera-tak-ze-ini-tu-nemaju-miesto-dennik-n> (2017)

11. A. Harumová, K. Kubátová, Business Taxes. (Žilina: Poradca podnikatel’a, 2006)

12. P. Markovič, H. Majdúchová, D. Rybárová, Stress Techniques - Innovation of Risk Management Methods. (Praha: Wolters Kluwer, 2018)

13. V. Konečná, A. Andrejovská, Investor Decision-making in the Context of the Effective Corporate Taxation. E\&M Economics and Management, 23(1), 111-120 (2020)

14. K. A. Clausing, Corporate tax revenues in OECD countries. International tax and public finance, 14(2), 115-133 (2007)

15. L. Mura, Entrepreneurship internationalization - case of Slovak family businesses. $A d$ Alta: Journal of Interdisciplinary Research, 9(1), 222-226 (2019)

16. N. Tačarová, Application of Tax Incentives in Selected EU Countries. University of Economics in Bratislava. Faculty of Business Management; Department of Corporate Finance. (Bratislava: FPM EU, 2019)

17. G. Dubcová, The Social and Solidarity Economy - One of the Stabilization Ways of Human Capital in Slovak Business. (Ljubljana: Dashöfer, 2018) 